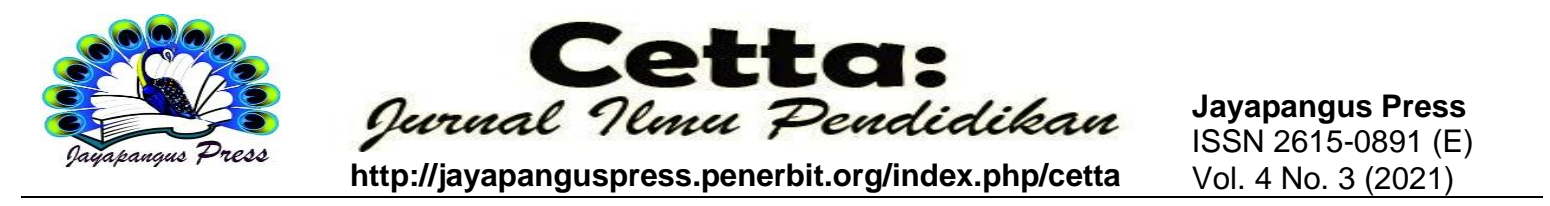

\title{
Evaluasi Persepsi Peserta Pada Pelatihan Manajemen Proyek
}

\section{Sri Mahendra Satria Wirawan}

Badan Pengembangan Sumber Daya Manusia Provinsi DKI Jakarta mahendrawirawan@gmail.com

\begin{tabular}{l}
\hline Keywords: \\
\hline Online, Project \\
Management, \\
Training \\
\hline
\end{tabular}

Abstract
Project problems such as wasted costs, poor quality, delays in
completion time and other impacts that have the potential to
cause legal consequences are often experienced. This happens
because the implementer ignores the principles of project
management in its implementation as a result of a poor
understanding of project management. For this reason, the DKI
Jakarta Provincial Human Resources Development Agency held
a Project Management training which during the Covid-19
pandemic was conducted online. Based on the analysis carried
out, from the participant aspect, it was found that the level of
satisfaction of the training participants was very high to a very
satisfactory level. The increase in participants' knowledge was
felt to be higher by participants with a background in social
education and humanities compared to participants with a
science and technology background. All participants said they
would apply the principles of project management because they
believe their competence has increased so that they can make a
positive contribution to improving the performance of their
agencies. Regarding the training aspect, the material was in
accordance with what was expected and needed in managing the
project. This training can be attended by participants from
various educational backgrounds, but the implementation time
needs to be considered for participants with social and
humanities backgrounds. In order to provide a better
understanding, online training needs to be combined with offline
in class. The training is felt to be very useful for improving the
competence of project managers, so it needs to be continued with
modification and development.

Kata Kunci:

Daring, Manajemen Proyek, Pelatihan

\begin{abstract}
Abstrak
Permasalahan proyek seperti pemborosan biaya, buruknya kualitas, keterlambatan waktu penyelesaian hingga dampak lain yang berpotensi menimbulkan konsekuensi hukum sering dialami. Hal ini terjadi karena pelaksana mengabaikan perinsip manajemen proyek pada implementasiya akibat dari pemahaman tentang manajemen proyek yang kurang baik. Untuk itu, Badan Pengembangan Sumber Daya Manusia
\end{abstract}




Provinsi DKI Jakarta mengadakan pelatihan Manajemen Proyek
yang pada saat pandemi Covid 19 dilakukan secara daring.
Berdasarkan analisa yang dilakukan, dari aspek peserta
dihasilkan bahwa tingkat kepuasan peserta pelatihan sangat
tinggi hingga mencapai level sangat memuaskan. Peningkatan
pegetahuan peserta dirasakan lebih tinggi oleh peserta dengan
latar belakang jurusan pendidikan sosial dan humaiora
dibandingkan dengan peserta dengan latar belakang sain dan
teknologi. Seluruh peserta mengatakan akan menerapkan
perinsip manajemen proyek karena yakin kompetensinya telah
meningkat sehingga dapat memberikan kontribusi positif bagi
peningkatan kinerja instansinya. Terhadap aspek pelatihan,
materi telah sesuai dengan apa yang diharapkan dan dibutuhkan
dalam mengelola proyek. Pelatihan ini bisa diikuti oleh peserta
dari berbagai latar belakang pendidikan, namun waktu
pelaksanaannya perlu dipertimbangkan untuk peserta dengan
latar belakang sosial dan humaniora. Agar dapat memberikan
pemahaman yang lebih baik, pelatihan secara daring perlu
dikombinasikan dengan tatap muka. Pelatihan dirasakan sangat
bermanfaat bagi peningkatan kompetensi pengelola proyek,
sehingga perlu dilanjutkan dengan modifikasi dan
pengembangan.

\section{Pendahuluan}

Dalam mencapai target kinerja Rencana Pembangunan Jangka Menengah Daerah (RPJMD), sebagai penjabaran visi dan misi Kepala Daerah terpilh pada setiap periode, pelaksanaan sebuah kegiatan dalam bentuk proyek menjadi sebuah keniscayaan yang akan direncanakan dan dilaksanakan oleh suatu daerah melaui seluruh Organisasi Perangkat Daerah (OPD) sesuai dengan urusan pemerintahan yang diembannya. Upaya mewujudkan sebuah target kinerja melalui pelaksanaan proyek, bukan merupakan suatu hal yang sederhana. OPD sering kali mengabaikan kaidah-kaidah manajemen proyek yang perlu diterapkan pada implementasiya. Hal ini tentu saja akan memberikan dampak dan akibat yang tidak sederhana. Dampak tersebut bisa terjadi dalam berbagai tingkatan, seperti pemborosan biaya proyek, buruknya kualitas yang dihasilkan, keterlambatan waktu penyelesaian proyek, hingga dampak lain yang berpotensi menimbulkan konsekuensi hukum.

Pada umumnya, Sumber Daya Manusia (SDM) pada setiap OPD, mempunyai latar belakang pendidikan sesuai dengan karakteristik urusan yang diemban oleh masingmasing OPD yang belum tentu memahami konsep manajemen proyek. Beragamnya latar belakang pendidikan dan pengetahuan tentang manajemen proyek tersebut menimbulkan 
tingkat pemahaman yang tingkatannya berbeda-beda. Kondisi ini tentu saja menyebabkan kaidah-kaidah manajemen proyek sering kali tidak diterapan pada setiap pelaksanaan kegiatan proyek. Penanggung jawab proyek di OPD menyerahkan sepenuhnya kepada pelaksana dan konsultan pengawas proyek, sehingga penanggung jawab proyek biasanya baru mengetahui bahwa pelaksanaan proyeknya menghadapi masalah pada saat akhir waktu pelaksanaan, sehingga mengakibatkan proyeknya tidak dapat diselesaikan tepat pada waktunya.

Waktu penyelesaian pelaksanaan proyek sering kali mundur atau terlambat karena tidak optimalnya pengendalian tenaga kerja, peralatan maupun materialnya, karena terjadi penyimpangan dari rencana yang telah ditetapkan. Kondisi ini dapat terjadi akibat pemantauan prestasi kemajuan pekerjaaan tidak terus menerus dipantau, sehingga penyimpangan terhadap rencana tidak segera dapat diketahui dan ditanggulangi (Sudipta, 2013). Keterlambatan dalam menyelesaikan suatu proyek merupakan masalah yang sering muncul dan dapat berdampak kepada seluruh pekerjaan dalam suatu proyek (Perdana \& Rahman, 2019).

Konsep manajemen proyek, yang dapat didefinisikan sebagai sebuah proses, yaitu bagaimana sebuah organisasi mengerjakan sesuatu dengan pendekatan yang sistematis untuk mencapai hasil akhir proyek dengan batasan-batasan anggaran biaya, jadwal dan kualitasnya (Soeharto, 1997), dalam merencanakan, mengorganisasikan, memimpin, dan mengendalikan kegiatan proyek, SDM serta sumber daya lainnya sehingga dapat mencapai sasaran proyek yang telah ditentukan, dengan tujuan agar dapat mengelola sumber daya secara efektif dan efisien sebagai upaya untuk dapat mengelola fungsi-fungsi manajemen secara optimal sesuai dengan persyaratan yang ditetapkan (Dimyati \& Nurjaman, 2014). Dapat pula dikatakan bahwa manajemen proyek adalah suatu cara taupun strategi yang perlu diterapkan guna efektifitas dan efisiensi pelaksanaan proyek yang dilakukan untuk mencapai tujuan organisasi (Ariani \& Puspitasari, 2017). Aspek-aspek yang perlu diperhatikan dalam manajemen proyek adalah aspek teknis, aspek manajerial dan administratif, aspek organisasi, aspek komersial, aspek finansial, serta aspek ekonomi (Slamet, 2016). Beberapa alat bantu yang biasa digunakan dalam manajemen proyek diantaranya adalah Program Evaluation and Review Technique (PERT), Critical Path Method (CPM) dan Gantt Chart sebagai alat bantu yang efektif dalam mengendalikan waktu dalam pelaksanaan proyek (Yusdiana dan Satyawisudarini, 2018) . 
PERT digunakan untuk melakukan penjadwalan, mengatur dan mengkoordinasikan bagian-bagian kegiatan dalam suatu proyek yang mencakup tiga perkiraan waktu Soeharto (2002): 1) waktu perkiraan pesimis, yaitu waktu paling lama yang dibutuhkan untuk menyelesaikan sebuah kegiatan; 2) waktu realistis, yaitu waktu penyelesaian sebuah kegiatan yang paling realistis; 3) waktu optimis, yaitu waktu tercepat yang dapat dilakukan untuk melaksanakan sebuah kegiatan. CPM atau metode jalur kritis merupakan analisa jaringan kerja yang berusaha mengoptimalkan biaya total proyek melalui pengurangan atau percepatan waktu penyelesaian total proyek yang bersangkutan (Perdana \& Rahman, 2019). Teknik ini dikerjakan dengan menyusun jaringan kerja yang diidentifikasikan ke arah aktivitas-aktivitas dengan menggunakan perkiraan waktu sederhana pada tiap aktivitas yang menunjukkan lamanya waktu pelaksanaan: 1) Earliest Start Time, yaitu waktu tercepat suatu kegiatan dapat dimulai; 2) Latest Start Time, yaitu waktu paling lambat untuk memulai suatu kegiatan; 3) Earliest Finish Time, yaitu waktu tercepat kegiatan dapat diselesaikan; 4) Latest Finish Time, yaitu waktu paling lambat dalam menyelesaikan suatu kegiatan. Pada CPM akan dapat digambarkan jalur kritis atau critical path yang bertujuan untuk mengetahui kegiatan-kegiatan yang memiliki tingkat kepekaan tinggi terhadap keterlambatan pelaksanaan, sehingga dapat menentukan tingkat prioritas kebijakan dalam penyelenggaraan proyek. Diagram CPM dapat memberikan informasi terkait dengan lamanya kegiatan serta kegiatan yang harus dilaksanakan terlebih dahulu dan kegiatan yang harus dilaksanakan sesudahnya,durasi kegiatan. Selanjutnya, jaringan pekerjaan yang telah digambarkan dalam CPM dapat dijadikan dasar untuk menyusub jadwal proyek. Penjadwalan proyek tersebut dapat digambarkan dalam bentuk diagram penjadwalan waktu atau time schedule dalam bentuk Gantt Chart.

Berdasarkan pertimbangan diatas, sejak tahun 2020, Badan Pengembangan Sumber Daya Manusia (BPSDM) Provinsi DKI Jakarta melaksanakan kembali pelatihan Manajemen Proyek bagi Aparatur Pemerintah Provinsi DKI Jakarta yang sejak beberapa tahun belakangan tidak dilaksankan. Namun pada disaat merebaknya pandemi Covid 19, pelatihan Manajemen Proyek dilakukan secara daring. Untuk itu, perlu dilakukan evaluasi terhadap pelaksanaannya sebagai salah satu bagian yang tidak terpisahkan dari proses pembelajaran untuk meningkatkan kualitas pembelajaran dalam pelatihan (Badu, 2012). Evaluasi persepsi terhadap peserta pelatihan perlu dilakukan agar dapat mengetahui sampai dimana tingkat kepuasan peserta terhadap pengampu mata pelatihan, hasil belajar peserta, perubahan sikap dan perilaku peserta, serta konrtibusi peserta dalam pencapaian 
target kinerja pelaksanaan proyek. Disamping itu dalam rangka keberlanjutan pelaksanaan pelatihan selanjutnya perlu pula dievaluasi konteks tujuan pelatihan, latar belakang pendidikan peserta dan materi yang diberikan sebagai input pelatihan, proses penyelenggaraan pelatihan, serta produk yang dihasilkan dari pelatihan dan dampaknya terhadap pelaksanaan kegiatan proyek dalam upaya pencapaian target kinerja organisasi guna mendukung pencapaian target RPJMD Pemprov. DKI Jakarta 2018-2022.

\section{Metode}

Jenis penelitian yang dilakukan adalah penelitian deskriptif sebagai salah satu jenis penelitian yang sering digunakan untuk mendapatkan gambaran atau deskripsi tentang fenomena sitiasi yang diteliti. Penelitian deskriptif biasanya dilakukan dengan maksud untuk Menyusun deskripsi sistematis, faktual, dan akurat tentang fakta-fakta dan sifat-sifat populasi (Suryana, 2010). Dalam pelaksanaannya, dilakukan survei untuk mengidentifikasi fakta-fakta dan informasi yang ada pada populasi kecil maupun besar.

Penelitian dilakukan di Jakarta pada bulan Maret - Mei 2021 dengan memakai data primer yang dikumpulkan berdasarkan kusioner yang dikumpulkan dari para peserta pelatihan Manajemen Proyek yang diprogramkan pada tahun 2021 pada Badan Pengembangan Sumber Daya Manusia Provinsi DKI Jakarta sebanyak dua Angkatan yaitu Angkatan IX, sebanyak 30 peserta dan Angkatan X sebanyak 30 peserta. Metode yang digunakan pada peelitan ini adalah metode kualitatif deskriptif agar dapat memberikan gambaran persepsi peserta secara holistik terhadap pelatihan Manajemen Proyek (Arikunto, 2010). Pendekatan model evaluasi yang digunakan adalah model Kirkpatrick dengan manganalisa persepsi peserta yang mencakup aspek reaksi, belajar, prilaku dan hasil (Kirkpatrick, 2006), yang dikombinasikan dengan pendekatan evaluasi CIPP sebagai salah satu model evaluasi yang paling banyak dikenal dan diterapkan oleh para evaluator (Junanto dan Kusna, 2018). Model CIPP ini diimplementasikan dengan melakukan evaluasi yang mencakup aspek Contex, Input, Proses, dan Product (Stufflebeam, 1972).

Pada penilaian persepsi reaksi peserta, dilakukan analisa persepsi tingkat kepuasan terhadap pengampu mata pelatihan, penyelenggara pelatihan, serta pendapat peserta serta masukannya terhadap keberlanjutan pelatihan Manajemen Proyek dimasa mendatang. Terhadap pengampu mata pelatihan, dilakukan penilaian terhadap pengampu enam mata pelatihan utama dalam pelatihan Manajemen Proyek, yaitu 1) Pokok-Pokok 
Manajemen, 2) Manajemen Sumber Daya Proyek, 3) Manajemen Jadwal, Waktu, Mutu dan Biaya Proyek, 4) Manajemen Pengadaan Barang/Jasa, 5) Manajemen Keselamatan dan Kesehatan Kerja atau K3 dan Lingungan, serta 6) Manajemen Resiko dan Rantai Pemasok. Untuk penyelenggara, dilakukan penilaian terhadap 1) Keramahan Petugas, 2) pelayanan petugas, 3) penyampaian informasi jadwal pelatihan, serta 4) penegakkan disiplin peserta. Sedangkan untuk penyelenggaraan pelatihan penilaian dilakukan terhadap 1) durasi waktu pelatihan, 2) efektifitas pembelajaran daring, serta 3) akses dan operasional sistem kediklatan. Untuk penilaian persepsi hasil belajar peserta, dilakukan persepsi peserta terhadap pengetahuan tentang manajemen proyek sebelum pelatihan, serta peningkatan pengetahuan tentang manajemen proyek setelah mengikuti pelatihan. Persepsi peserta terhadap perubahan prilaku peserta dalam menerapkan kaidah kaidah manajemen proyek pada pelaksanaan tugas dalam setiap pelaksanaan proyek di unit kerjanya akan dinilai berdasarkan penerapan konsep atau perinsip manajemen proyek yang selama ini dilakukan, serta keinginan peserta untuk menerapkan konsep atau perinsip manajemen proyek setelah peserta kembali ketempat tugas. Persepsi peserta terhadap peningkatan kinerja akan dinilai berdasarkan keyakinan peserta untuk dapat memberikan kontribusi positif bagi peningkatan kinerja unit kerja setelah mengikuti pelatihan. Disamping itu, semua persepsi yang diberikan peserta pada aspek reaksi tingkat kepuasan, hasil belajar, perubahan sikap prilaku dan peningkatan kinerja sebelum dan sesudah peserta mengikuti pelatihan akan dilihat keterkaitannya dengan latar belakang pendidikan peserta.

Penilaian konteks dilakukan untuk melihat sejauhmana rencana, tujuan dan hasil yang dicapai dalam pelatihan Manajemen Proyek. Persepsi peserta dinilai berdasarkan kesesuaian materi pelatihan dengan dengan apa yang diharapkan dan dibutuhkan dalam pengelolaan kegiatan proyek di lingkungan OPD. Terhadap aspek input, dilakukan penilaian persepsi peserta terhadap pengaruh latar belakang pendidikan terhadap hasil pendidikan, sehingga diketahui apakah latar pendidikan peserta pelatihan sesuai dengan materi yang akan diberikan. Untuk proses penyelenggaraan, persepsi peserta akan digali terkait dengan waktu pelatihan, apakah durasi pelatihan dirasakan mencukupi untuk memahami matri yang diperlukan. Kondisi ini juga kan dikaitkan dengan efektifitas pelatihan daring yang dilakukan pada pelatihan Manajemen Proyek. Disamping itu, penilaian terhadap produk pelatihan akan dilakukan dengna menganlisa persepsi peserta terhadap kemanfaatan pelatihan ini untuk peningkatan kompetensi pengelola kegiatan di 
OPD, sehingga menimbulkan keinginan peserta untuk memberikan rekomendasi kepada pimpinannya agar mengikutsertakan para pengelola kegiatan proyek pada pelatihan Manajemen Proyek.

\section{Hasil dan Pembahasan}

Dari 30 orang peserta pelatihan Manajemen Proyek Angkatan IX, seluruhnya memberikan jawaban terhadap kuesioner yang diberikan. Sementara untuk Angkatan X, kuesioner hanya diisi oleh 28 orang, karena 2 orang peserta mengundurkan diri. Peserta dari dua angkatan pelatihan Manajemen Proyek sebagai responden secara keseluruhan hampir menunjukkan karakteristik Pendidikan yang sama, hanya pada angkatan IX terdapat dua orang dengan tingkat pendidikan S3, sementara pada angkatan X tidak ada. Untuk angkatan IX, 53,3\% peserta memiliki tingkat pendidikan S2, 40,0\% dengan tingkat Pendidikan S1 dan 6,7\% dengan tingkat Pendidikan S3, sedangkan angkatan X, 53,6\% peserta memiliki tingkat pendidikan S2 dan 46,4\% dengan tingkat Pendidikan S1. Jika dilihat dari spesialisasi jurusan pendidikannya, peserta pelatihan angkatan IX, jurusan pendidikan peserta didominasi oleh jurusan sain dan teknologi, yaitu $70 \%$, sedangkan sisanya yang $30 \%$ dari jurusan sosial dan humaiora, namun peserta pelatihan pada angkatan $\mathrm{X}$, prosentasenya berimbang masing-masing $50 \%$ baik jurusan sain dan teknologi maupun sosial dan humaiora.

\section{Persepsi Peserta Terhadap Pengampu Dan Penyelenggara}

Dalam evaluasi terhadap reaksi peserta pelatihan Manajemen Proyek, tingkat kepuasan peserta terhadap pengampu enam mata pelatihan utama dalam pelatihan Manajemen Proyek, yaitu Pokok-Pokok Manajemen, Manajemen Sumber Daya Proyek, Manajemen Jadwal, Waktu, Mutu dan Biaya Proyek, Manajemen Pengadaan Barang/Jasa, Manajemen K3 dan Lingungan serta Manajemen Resiko dan Rantai Pemasok. Penilaian dilakukan secara keseluruhan terhadap aspek 1) kualitas bahan tayang, 2) penguasaan materi, 3) metode penyampaian dan penguasaan teknologi informasi, 4) cara menjawab pertanyaan, serta 5) pemberian motivasi kepada peserta, menunjukan bahwa secara rata-rata peserta angkatan IX memberikan nilai tingkat kepuasan $83,67 \%$, sementara peserta angkatan X memberikan nilai tingkat kepuasan 90,95\%, lebih tinggi dibandingkan dengan nilai tingkat kepuasan peserta angkatan IX. Secara lengkap gambaran tentang hal ini dapat dilhat pada Gambar 1 dan Gambar 2 dibawah ini. 


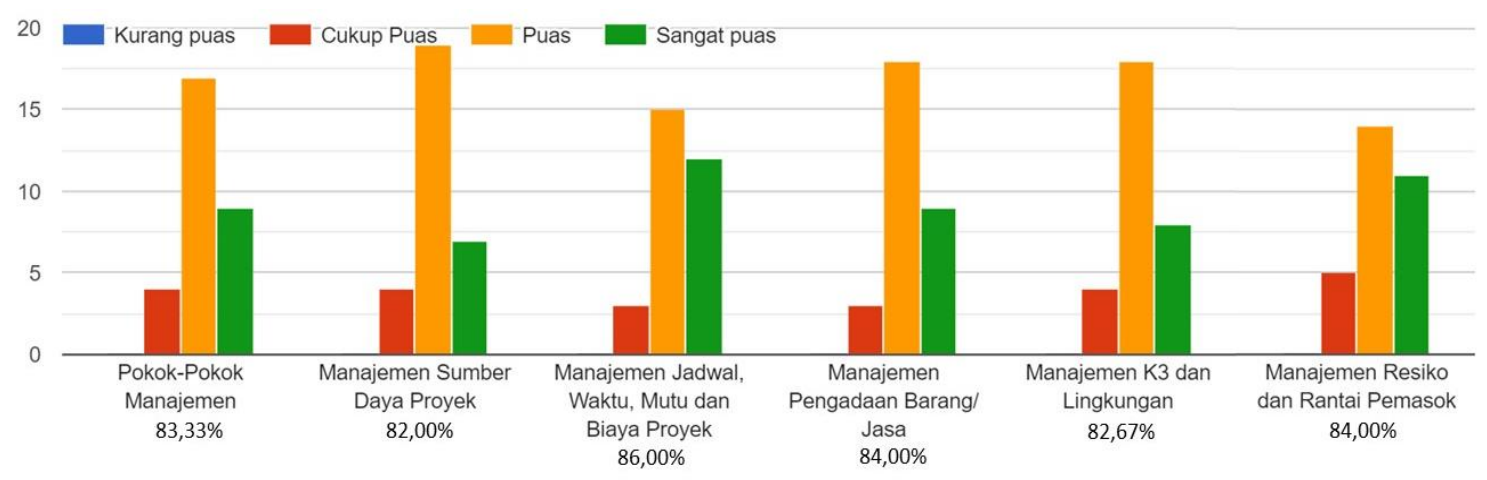

Gambar 1. Tingkat Kepuasan Peserta Angkatan IX Terhadap Pengampu

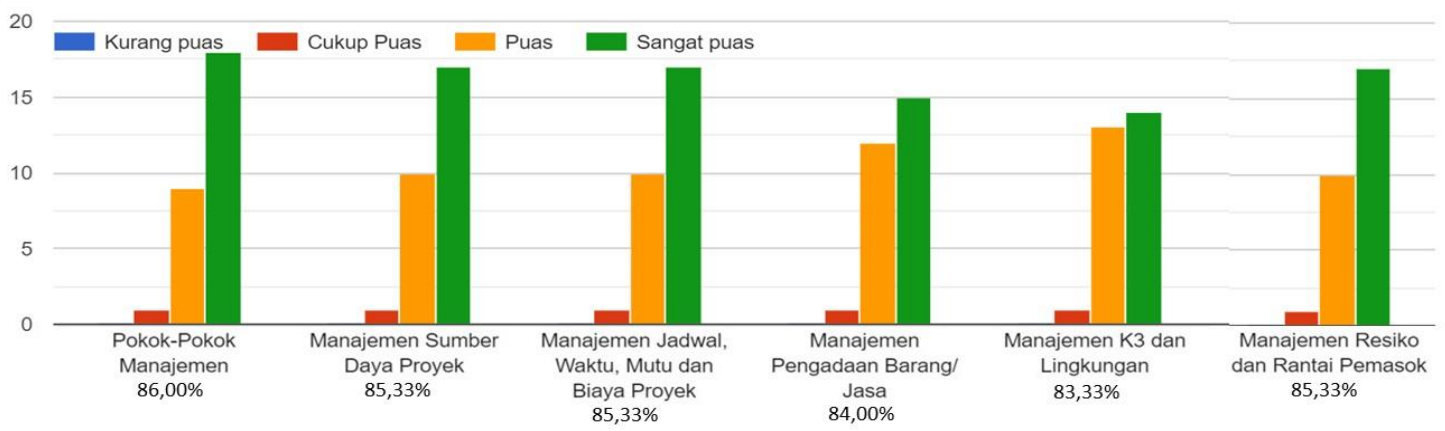

Gambar 2. Tingkat Kepuasan Peserta Angkatan X Terhadap Pengampu

Jika dilihat dari jurusan pendidikan peserta, untuk angkatan IX, yang didominasi oleh jurusan sain dan teknologi, sementara untuk angkatan $\mathrm{X}$, prosentase peserta dari jurusan Pendidikan sain dan teknologi yang sama dengan prosentase peserta jurusan pendidikan sosial dan humaniora, mengindikasikan bahwa jurusan pendidikan mempengauhi tingkat kepuasan peserta pelatihan terhadap pengampu mata pelatihan pada pelatihan Manajemen Proyek. Peserta dari jurusan pendidikan sosial dan humaniora memberikan tingkat kepuasan yang lebih tinggi dibandingkan dengan peserta dengan jurusan Pendidikan sain dan teknologi.

Tingkat kepuasan peserta terhadap penyelenggara pelatihan yang dinilai berdasarkan keramahan petugas, pelayanan petugas, penyampaian informasi jadwal pelatihan dan penegakkan disiplin peserta, untuk peserta angkatan IX memberikan nilai tingkat kepuasan sebesar $88,00 \%$, sementara angkatan $\mathrm{X}$ memberikan nilai tingkat kepuasan sebesar 91,43\%, lebih tinggi dibanding dengan nilai tingkat kepuasan angkatan IX. Sejalan dengan tingkat kepuasan peserta pelatihan terhadap pemgampu pelatihan, Peserta dari jurusan pendidikan sosial dan humaniora juga memberikan tingkat kepuasan yang lebih tinggi dibandingkan dengan peserta dengan jurusan Pendidikan sain dan teknologi. 
Jika merujuk pada Keputusan Kepala Lembaga Administrasi Negara Nomor 1007/K.1/PDP.07/2019 tentang Pedoman Penyelenggaraan Pelatihan Kepemimpinan Administrator (LAN RI, 2019), kategori kriteria tingkat kepuasan peserta dapat dilihat pada Tabel 1 berikut.

Tabel 1. Kriteria tingkat kepuasan

\begin{tabular}{cc}
\hline NILAI & KATEGORI \\
\hline$>90 \%-100 \%$ & Sangat Memuaskan \\
$>80 \%-90 \%$ & Memuaskan \\
$>70 \%-80 \%$ & Cukup Memuaskan \\
$>60 \%-70 \%$ & Kurang Memuaskan \\
$\leq 60 \%$ & Tidak memuaskan
\end{tabular}

Berdasarkan kriteria diatas, tingkat kepuasan peserta pelatihan Manajemen Proyek angkatan IX terhadap pengampu yang memberikan nilai $83,67 \%$, berada dalam kategori memuaskan, sementara tingkat kepuasan peserta terhadap penyelenggara sebesar $88,00 \%$, juga berada pada level memuaskan. Namun untuk pelatihan Manajemen Proyek angkatan $\mathrm{X}$, tingkat kepuasan peserta terhadap pengampu nilainya lebih tinggi, yaitu $90,95 \%$, sehingga berada pada level sangat memuaskan. Demikian pula halnya untuk tingkat kepuasan peserta terhadap penyelenggara, yaitu sebesar $91,43 \%$, sehingga tingkat kepuasan peserta terhadap penyelenggara pelatihan juga berada pada level sangat memuaskan.

Pada penilaian terhadap pengampu, hal ini sejalan dibandingkan dengan penilaian peserta Pelatihan Kepemimpinan Administrator yang tingkat kepuasan peserta terhadap pengampu mencapai $91,53 \%$, atau berada dalam kategori sangat memuaskan. Namun sedikit berbeda dengan tingkat kepuasan peserta terhadap penyengaara pelatihan menunjukkan rata-rata angka yang mencapai $89,81 \%$, atau berada dalam kategori memuaskan (Mahendra dan Sembiring 2021).

\section{Persepsi Peserta Terhadap Hasil Pelatihan}

Evaluasi hasil belajar yang dilakukan berdasarkan persepsi peserta terhadap hasil pelatihan, dapat dilihat bahwa secara umum sebelum mengikuti pelatihan, peserta yang mengatakan mengetahui dan sangat mengetahui tentang manajemen proyek adalah berimbang. Dari angkatan IX menunjukan prosentase sebanyak 33,4\%, sementara 
angkatan X sebanyak 32,2\%. Disini terlihat pula bahwa peserta angkatan IX yang didominasi oleh peserta dengan latar belakang yang lebih dominan dari jurusan sain dan teknologi prosentase peserta yang sangat kurang pengetahuannya dalam hal manajemen proyek lebih kecil, yaitu 23,3\%, dibandingkan dengan angkatan $\mathrm{X}$ yang prosentase peserta dengan jurusan pendidikan sain dan teknologinya lebih sedikit yang mencapai 42,9\%. Setelah melaksanakan pelatihan, semua peserta dari kedua angkatan mengatakan bahwa tingkat pengetahuannya tentang manajemen proyek meningkat. Peserta pelatihan Angkatan IX yang mengatakan bahwa pengetahuanya tentang manajemen proyek meningkat dan sangat meningkat mencapai 86,7\%, sementara peserta pelatihan Angkatan $\mathrm{X}$ mencapai $89,3 \%$, sedangkan sisanya sebesar $13,3 \%$ peserta angkatan IX dan 10,7\% peserta angkatan $\mathrm{X}$ mengatakan sedikit meningkat. Disini terlihat bahwa peningkatan pegetahuan tentang manajemen proyek dirasakan lebih tinggi pada angkatan $\mathrm{X}$ yang prosentase latar belakang jurusan pendidikan sain dan teknologinya lebih sedikit dibandingkan dengan prosentase peserta angkatan IX.

Hal ini sejalan dengan penelitian sebelumnya yang dilakukan terhadap Pelatihan Kepemimpinan Administrator di lingkungan Pemerintah Provinsi DKI Jakarta, dimana hasil belajar pesertanya menunjukkan peningkatan yang signifikan setelah mengikuti pelatihan (Mahendra dan Sembiring 2021). Demikian pula halnya terhadap pelatihan yang dilakukan untuk meningkatkan pengetahuan dan kemampuan Pegawai Pegadaian dalam pelaksanaan tugas yang mengatakan bahwa setelah mengikuti pelatihan, secara umum hasil perolehan hasil belajar para peserta pelatihan meningkat dengan perbedaan yang signifikan (Aminah, 2015).

\section{Persepsi Peserta Terhadap Perubahan Sikap}

Terhadap penerapan konsep atau perinsip manajemen proyek, prosentase yang selama ini tidak pernah menerapkannya dalam pelaksanaan tugas sehari hari, pada peserta angkatan IX lebih kecil, yaitu 6,7\%, sementara pada peserta angkatan X, prosentase yang tidak pernah menerapkannya mencapai $28,6 \%$. Kondisi ini mengindikasikan bahwa peserta dengan latar belakang jurusan pendidikan sain dan teknologi lebih terbiasa menerapkan perinsip manajemen proyek dalam setiap pelaksanaan tugasnya. Namun demikian, setelah mengikuti pelatihan Manajemen Proyek, seluruh peserta mengatakan akan selalu menerapkan dan menerapkan sesuai kebutuhan pelaksanaan kegiatannya, termasuk 3,3\% peserta angkatan IX yang akan menerapkannya jika diperintah atasan. 
Terlihat bahwa tidak terdapat perbedaan antara peserta dengan latar belakang jurusan pendidikan sain dan teknologi dengan sosial dan humaniora. Disamping itu, seluruh peserta menyatakan kemauannya dan kemungkinan untuk menjelaskan kepada pimpinannya tentang pemahaman dan penerapan manajemen proyek pada setiap pelaksanaan tugas.

Perbaikan sikap dalam pelaksanaan pekerjaan ini terjadi karena setelah peserta tersebut mengikuti program pelatihan pasti akan muncul perubahan perilaku dalam pelaksanaan pekerjaaan (Tan dan Newman, 2013). Kondisi ini sejalan dengan penelitian yang dilakukan bagi pegawai Direktorat Jendral Bina Marga Semarang, dimana hasilnya membuktikan bahwa teah terjadi perubahan perilaku peserta pasca pelatihan (Rustiana, 2010).

\section{Persepsi Peserta Terhadap Peningkatan Kinerja}

Persepsi peserta terhadap peningkatan kinerja peserta setelah mendapatkan pelatihan disampaikan bahwa 93,3\% peserta angkatan IX meyakini kinerjanya akan meningkat dan hanya $6,7 \%$ peserta yang ragu-ragu. Sementara itu, untuk peserta angkatan $\mathrm{X}$, seluruhnya atau $100 \%$ yakin bahwa kinerja mereka akan meningkat setelah mengikuti pelatihan. Disamping itu, peserta pelatihan Manajemen Proyek angkatan IX dan angkatan $\mathrm{X}$ juga meyakini bahwa melalui pelatihan ini, peserta akan dapat memberikan kontribusi positif bagi peningkatan kinerja OPD.

Berdasarkan penelitan terhadap Peranan Pelatihan dalam Peningkatan Kinerja Karyawan PT PLN Pembangkitan Sumatera Selatan, telah terjadi peningkatan prestasi kerja karyawan setelah mendapat pelatihan. Pelaksanaan pelatihan telah dapat meningkatkan keterampilan karyawan, sehingga kinerja dalam pelaksanaan pekerjan menjadi lebih baik (Elisa et al, 2014).

\section{Persepsi Peserta Terhadap Kesesuaian Materi Pelatihan}

Dalam kontek materi, kesesuaian materi pelatihan dengan apa yang diharapkan dan dibutuhkan dalam mengelola kegiatan proyek di lingkungan OPD peserta dirasakan sangat sangat membantu. Peserta angkatan IX yang mengatakan sesuai mencapai 86,7\%, sedangkan sisanya yang 13,3\% mengatakan cukup sesuai. Disamping itu, 92,1\% peserta angkatan X mengatakan bahwa materi yang dibutuhkan sesuai dengan yang diharapkan dan dibutuhkan, sedangkan selebihnya $7,1 \%$ mengatakan cukup sesuai, lebih sedikit 
disbanding dengan peserta angkatan X. Dari dua angkatan pelatihan Manajemen Proyek yang dilakukan, tidak ada satupun peserta yang mengatakan bahwa materi pelatihannya tidak sesuai dengan yang diharapkan dan dibutuhkan peserta. Secara umum tujuan dan kesesuaian meteri dalam pelatihan ini ditanggapi positif oleh para peserta pelatihan Manajemen Proyek, sehingga untuk angkatan IX hanya 7\% peserta yang memberikan saran perbaikan terhadap hal ini, sementara untuk angkatan $\mathrm{X}$ peserta yang memberikan saran perbaikan sebanyak $11 \%$.

Hal ini dapat dikatakan bahwa perencanaan yang dilakukan oleh penyelenggara maupun pengampu pelatihan Manajemen Proyek telah sesuai, karena telah melibatkan berbagai pemangku kepentingan sebagaimana teori yang menjelaskan bahwa sebelum pelatihan, salah satu peran penyelenggara pelatihan adalah merencanakan program pelatihan dengan melibatkan para pemangku kepentingan untuk menganalisis kebutuhan materi pelatihan yang diperlukan (Lynton dan Pareek, 2011).

\section{Persepsi peserta terhadap pengaruh latar belakang Pendidikan terhadap hasil Pendidikan}

Jika dilihat pengaruh latar belakang pendidikan terkait dengan pemahaman terhadap materi pelatihan, $80,0 \%$ peserta angkatan IX mengatakan mempengaruhi dan sangat mempengaruhi, $13,3 \%$ sedikit mempengaruhi dan 6,7\% tidak mempengaruhi. Sementara untuk angkatan $\mathrm{X}$, sedikit berbeda, yaitu 78,5\% peserta mengatakan tidak mempengaruhi dan sangat mempengaruhi, 17,9\% sedikit mempengaruhi dan 3,6\% tidak mempengaruhi. Kondisi diatas sejalan dengan persepsi peserta terhadap kesesuaian pendidikan untuk mengikuti pelatihan manajemen proyek. Sebagian besar peserta angkatan IX, yaitu $60 \%$ peserta mengatakan semua latar belakang pendidikan sesuai untuk mengikuti pelatihan ini, namun $40 \%$ mengatakan yang lebih sesuai adalah latar belakang sain dan teknologi. Sedangkan pada angkatan X, 64,3\% peserta, lebih besar dari angkatan IX, mengatakan semua latar belakang pendidikan sesuai untuk mengikuti pelatihan ini dan 35,7\% mengatakan yang lebih sesuai adalah latar belakang sain dan teknologi Hal ini tentu saja dapat menjadi acuan bagi penyelenggara dalam melakukan seleksi peserta dalam menentukan latar belakang pendidikan calon peserta. Untuk meningkatkan kualitas pelatihan Manajemen Proyek ini, 40\% peserta angkatan IX menyarankan untuk mempertimbangkan komposisi latar belakang pendidikan peserta, sementara untuk angkatan X yang menyarankan hal tersebut sebanyak $28 \%$. 
Evaluasi input terhadap latar belakang peserta dilakukan untuk mengidentifikasi dan mengukur kemampuan peserta. Aspek yang dievaluasi dalam dimensi ini adalah latar belakang pendidikan peserta pelatihan sebagai salah satu faktor yang paling berpengaruh dalam keberhasilan program pelatihan. Hal ini sejalan dengan pernyataan bahwa keberhasilan kegiatan pelatihan akan dipengaruhi oleh kesiapan peserta (Fitri, 2016).

\section{Persepsi Peserta Terhadap Penyelenggaraan}

Persepsi terhadap durasi waktu untuk pelatihan untuk memahami materi pelatihan Manajemen Proyek, peserta pelatihan angkatan IX sejumlah 70,0\% mengatakan cukup, sementara 30\% peserta mengatakan kurang. Sedangkan untuk angkatan X, 64,2\% peserta mengatakan cukup, lebih tinggi dibanding angkatan IX, sementara 35,7\% peserta mengatakan kurang. Selanjutnya terkait dengan persepsi peserta terhadap efektifitas pembelajaran daring pelatihan manajemen proyek, hanya $36,7 \%$ peserta pelatihan angkatan IX mengatakan bahwa pelatihan Manajemen Proyek secara daring dirasakan efektif, sedangkan $63,3 \%$, mengatakan bahwa pelatihan perlu dipadukan dengan tatap muka atau blended learning. Untuk angkatan X, 42,9\% peserta mengatakan efektif, sementara $57,1 \%$ peserta mengatakan bahwa pelatihan perlu dipadukan dengan tatap muka. Hai ini sejalan dengan penelitian yang dilakukan pada Evaluasi Pelaksanaan Pelatihan Kepemimpinan Administrator Daring yang dilakukan oleh Badan Pengembangan Sumber Daya Manusia Provinsi DKI Jakarta tahun 2020 (Wirawan dan Sembiring, 2021). Dalam hal akses dan akses dan operasional sistem kediklatan pada pelatihan Manajemen Proyek ini, 93,3\% peserta angkatan IX mengatakan bahwa sistem kediklatan mudah diakses, sementara yang mengatakan cukup mudah sebesar $6,7 \%$. Terhadap hal yang sama, 92,9\% peserta angkatan X mengatakan mudah, sedangkan $7,1 \%$ mengatakan cukup mudah. Terhadap proses penyelenggaraan pelatihan, $43 \%$ peserta pelatihan baik angkatan IX maupun angkatan X menyarankan untuk meningkatkannya, terutama terkait dengan durasi waktu pelatihan. Evaluasi proses ini sejalan dengan penelitian tentang penggunaan model Konteks, Input, Proses, dan Produk (CIPP) dalam evaluasi program pelatihan untuk mengamati setiap aktivitas proses yang dilakukan selama pelatihan program termasuk penggunaan metode ((Umam dan Saripah, 2018). 


\section{Persepsi Peserta Terhadap Keluaran Pelatihan}

Untuk keluaran dari pelatihan Manajemen Proyek ini, 100\% atau seluruh peserta angkatan IX mengatakan bahwa pelatihan Manajemen Proyek ini memberikan manfaat bagi peningkatan kompetensi pengelola kegiatan OPD, sedangkan pada angkatan $\mathrm{X}$, 96,4\% peserta mengatakan bahwa pelatihan ini bermanfaat bagi peningkatan kompetensi pengelola kegiatan OPD dan 3,6\% mengatakan hanya sedikit bermanfaat. Utuk itu, 90,0\% peserta angkatan IX mengatakan akan merekomendasikan kepada pimpinanya agar mengikutsertakan para pengelola kegiatan OPD pada pelatihan Manajemen Proyek, sedangkan 10,0\% peserta akan mempertimbangkan untuk merekomendasikan kepada pimpinannya. Untuk angkatan X, seluruh peserta atau 90,0\% peserta mengatakan akan merekomendasikan kepada pimpinanya agar mengikutsertakan para pengelola kegiatan OPD pada pelatihan Manajemen Proyek. Berdasarkan hal tersebut, untuk keberlanjutan pelaksanaan pelatihan Manajemen Proyek, 93,7\% peserta angkatan IX dan 92,9\% peserta angkatan X mengatakan bahwa pelatihan agar dilanjutkan dengan modifikasi dan pengembangan baik materi maupun penyelenggaraannya. Hal ini sejalan dengan penelitian tentang dampak pelatihan keterampilan manajemen proyek Pada Lembaga Sosial Masyarakat yang mengatakan behwa pelatihan dimaksud sangat memberikan manfaat sehingga membuat para peserta pelatihan merekomendasikan keberlanjutan program pelatihan ini (Sari et.al., 2020).

\section{Kesimpulan}

Berdasarkan pembahasan dan analisa yang telah disampaikan, disimpulkan tingkat kepuasan peserta pelatihan Manajemen Proyek terhadap pengampu mata pelatihan maupun penyelenggara pelatihan, yang diberikan oleh peserta angkatan $\mathrm{X}$ berada pada level sangat memuaskan, lebih tinggi dibanding dengan angkatan IX yang berada pada level memuaskan. Untuk hasil belajar, peningkatan pegetahuan tentang manajemen proyek dirasakan lebih tinggi oleh peserta angkatan X dibandingkan dengan peserta angkatan IX. Terhadap perubahan sikap dan perilaku, setelah mengikuti pelatihan Manajemen Proyek, seluruh peserta baik angkatan IX maupun angkatan X mengatakan akan menerapkannya dalam setiap pelaksanaan kegiatan. Terkait peningkatan kinerja, seluruh peserta meyakini bahwa kinerja mereka akan meningkat setelah mengikuti pelatihan serta juga meyakini akan dapat memberikan kontribusi positif bagi peningkatan kinerja instansi. 
Secara umum, materi yang diberikan dalam pelatihan Manajemen Proyek telah sesuai dengan apa yang diharapkan dan dibutuhkan dalam mengelola kegiatan proyek, serta dirasakan sangat sangat membantu peserta dalam mengelola proyek. Latar belakang pendidikan peserta dalam pelatihan ini berpengaruh terhadap tingkat pemahaman peserta terhadap materi pelatihan. Walaupun peserta dengan latar belakang sain dan teknologi dirasakan lebih mudah memahami materi dibandingkan dengan yang berlatar belakang sosial dan humaniora, namun secara keseluruhan, pelatihan ini bisa diikuti oleh peserta dari berbagai latar belakang Pendidikan. Waktu pelaksanaan yang dialokasikan pada pelatihan ini dirasakan sudah mencukupi, namun perlu dipertimbangkan untuk peserta dengan latar belakang sosial dan humaniora dapat diberikan alokasi waktu yang lebih lama. Disamping itu, pelaksanaan pelatihan yang dilakukan secara daring perlu dikombinasikan dengan tatap muka agar dapat memberikan pemahaman yang lebih baik. Pelatihan Manajemen Proyek dirasakan sangat memberikan manfaat bagi peningkatan kompetensi pengelola kegiatan proyek, sehingga pelatihan ini perlu dilanjutkan dengan modifikasi dan pengembangan baik materi maupun penyelenggaraannya.

\section{Daftar Pustaka}

Aminah, H. (2015). Model Evaluasi Kirikpatrick Dan Aplikasinya Dalam Pelaksanaan Pelatihan (Level Reaksi dan Pembelajaran) di Pusat Pendidikan dan Pelatihan Perum Jakarta. Jurnal Riset Manajemen Sains Indonesia, 6(1), 376-394. http://journal.unj.ac.id/unj/index.php/jrmsi/article/view/540/467

Arianie, PD., Puspitasari NB. (2017). Perencanaan Manajemen Proyek Dalam Meningkatkan Efisiensi Dan Efektifitas Sumber Daya Perusahaan (Studi Kasus: Qiscus Pte Ltd). Jurnal Teknik Industri, 12(3), 189-196.

Arikunto, S. (2010). Prosedur Penelitian Suatu Pendekatan Praktik. Rineka Cipta.

Badu, Q. (2012). Implementasi Evaluasi Model Kirkpatrick Pada Perkuliahan Masalah Nilai Awal dan Syarat Batas. Jurnal Penelitian Dan Evaluasi Pendidikan, 16(Edsi Dies Natalis ke-48 UNY), 102-129.

Dimyati, D. H., \& Nurjaman, K. (2014). Manajemen Proyek. Yogyakarta: Pustaka Setia. Elisa, Efendi, MRM., Sari, NI., (). Peranan Pelatihan dalam Peningkatan Kinerja Karyawan (Studi Kasus Bagian Operasional PT PLN (PERSERO) Pembangkitan Sumatera Selatan Bagian Selatan. Jurnal Orasi Bisnis, 12(2), 92-105. 
Fitri, R (2016). Pengaruh Pelatihan Terhadap Kinerja Karyawan Pada Pt. BNI Syariah Cabang Utama Kota Pekanbaru. 3(2): 1-9.

Junanto, S., Kusna, NAA,. (2018). Evaluasi Program Pembelajaran di PAUD Inklusi dengan Model Context, Input, Process, and Product (CIPP). Journal of Disability Studies. 5(2), 179-194.

Lembaga Adminisrasi Negara, (2019), Keputusan Kepala Lembaga Administrasi Negara Nomor 1007/K.1/PDP.07/2019 tentang Pedoman Penyelenggaraan Pelatihan Kepemimpinan Administrator.

Kirkpatrick, Donald L. 2006. Implementing The Four Levels. San Fransisco: BerretKoehler Publisher, Inc.

Lynton, RP., Pareek, UN. (2011). Training for Development. SAGE Publications.

Perdana, S., Rahman, A. (2019). Penerapan Manajemen Proyek Dengan Metode CPM (Critical Path Method) Pada Proyek Pembangunan SPBE. Jurnal Pengabdian Kepada Masyarakat. 3(1), 243-250.

Rustiana, A. (2010). Efektivitas Pelatihan Bagi Peningkatan Kinerja Karyawan. Jurnal Dinamika Manajemen. 1(2), 137-143.

Sari, DA., Suprayogo, T., Isyanto, AY., Roshonah, AF. (2020). Dampak Pelatihan Keterampilan Manajemen Proyek Pada Lembaga Sosial Masyarakat (LSM). Jurnal Pengabdian Masyarakat. 3(1), 1-9.

Slamet, K. (2016). Implementasi Mata Kuliah Manajemen Proyek Dalam Bentuk Pelaksanaan Proyek Mini. Jurnal Informasi Keuangan dan Akuntansi. 4(Juli), 121-142.

Soeharto, I. 1999. Manajemen Proyek (Dari Konseptual Sampai Operasional). Jakarta: Erlangga.

Stufflebeam, D. (1972). Educational Evaluation and Decising Making. Pecocok Publicers Inc.

Sudipta, IGK. (2013). Studi Manajemen Proyek Terhadap Sumber Daya Pada Pelaksanaan Proyek Konstruksi (Studi Kasus : Pembangunan Villa Bali Air). Jurnal Ilmiah Teknik Sipil. 17(1), 73-83.

Suryana, 2010, Metode Penelitian Model Praktis Penelitian Kuantitatif dan Kualitatif. Bandung: UPI 
Tan, K and Newman, E. (2013). The evaluation of sales force training in retail Organizations: A test of Kirkpatrick's four level model. International Journal of Management. 30(3), 692-703.

Umam, KA., Saripah, I. (2018). Using the Context, Input, Process and Product (CIPP) Model in the Evaluation of Training Programs. International Journal of Pedagogy and Teacher Education, 2(2), 183-194.

Wirawan, SMS., Sembiring, H. (2021). Evaluasi Pelaksanaan Pelatihan Kepemimpinan Administrator Daring. Jurnal Inspirasi Pendidikan. 11 (1), 19-27.

Yusdiana, Satyawisudarini, I. (2018). Penerapan Metode PERT dan CPM Dalam Pelaksanaan Proyek Pembangunan Jalan Paving Untuk Mencapai Efektivitas Waktu Penyelesaian Proyek. Jurnal Manajemen dan Bisnis. 2(3), 20-30. 